\title{
A HOSPITAL BASED STUDY ON PATTERN OF EXTREMITY FRACTURES FOLLOWING TRAUMA IN MANIPUR
}

Oinam Guneshwar Singh ${ }^{1}$, H. Shantikumar Singh ${ }^{2}$, S. Thoibahenba Singh ${ }^{3}$

${ }^{1}$ Associate Professor, Department of Orthopaedics, JNIMS.

${ }^{2}$ Assistant Professor, Department of Orthopaedics, JNIMS.

${ }^{3}$ Associate Professor, Department of Anaesthesiology, JNIMS.

\section{ABSTRACT}

\section{BACKGROUND}

A study on pattern of extremity fractures following trauma is important for public health planning.

Objective of this study is to find out pattern of both upper and lower extremity fractures following trauma in Manipur.

\section{MATERIALS AND METHODS}

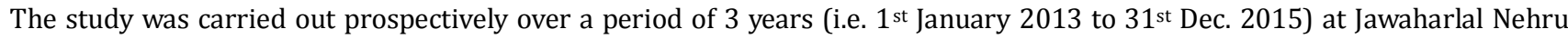
Institute of Medical Sciences, Imphal.

\section{RESULTS}

In upper extremity, fracture of lower end of radius was the most common followed by fracture of both bones of the forearm. In lower extremity, fracture of both bones of leg was the most common followed by fracture of metatarsal bones.

\section{CONCLUSIONS}

Thorough understanding of extremity fracture pattern in this part of the country may help in planning future preventive and management strategies.

\section{KEYWORDS}

Extremity Fractures, Pattern, Sensorium, OPD, Musculoskeletal Injuries RTA.

HOW TO CITE THIS ARTICLE: Singh OG, Singh HS, Singh ST. A hospital based study on pattern of extremity fractures following trauma in Manipur. J. Evolution Med. Dent. Sci. 2016;5(82):6097-6100, DOI: 10.14260/jemds/2016/1378

\section{BACKGROUND}

A fracture may be defined as a complete break in the continuity of a bone or, occasionally, it may be an incomplete break. It may be caused solely by a sudden violent injury, trivial injury, stress or certain medical conditions which weaken the bones. We human beings have to pay a heavy price due to altered fast life as a result of the rapid advent of progress in technology; these added to the fast life to meet the daily needs and are prone to accidents. These factors are precipitated by poorly developed roads leading to heavy casualty resulting in varied pattern of fractures and dislocations. Trauma picture follows a particular pattern, dictated by the huge movement of population to meet the social needs and during particular season namely rainy and summer. In high velocity injuries as a result of RTA (Road traffic accident), the fracture pattern and types are varied and challenging. It requires a highly effective trauma team care to prevent mortality and morbidity. The fractures and dislocations require highly skilled care. Accidents accounts for $5^{\text {th }}$ leading cause of mortality, which accounts for $5.2 \%$ of all mortality, according to 1996 WHO report. ${ }^{1}$ Though the rates have noticeably decreased in developed countries, still it is a burning problem in developing countries. ${ }^{2}$

Financial or Other, Competing Interest: None.

Submission 22-09-2016, Peer Review 03-10-2016,

Acceptance 05-10-2016, Published 11-10-2016.

Corresponding Author:

Dr. S. Thoibahenba Singh,

Department of Anaesthesiology,

Jawaharlal Nehru Institute of Medical Sciences,

Porompat,

Imphal.

E-mail: thoibas@gmail.com

DOI: $10.14260 /$ jemds/2016/1378
The leading cause of death and disability for people under 45 years in the industrialised world is due to injury. The accident is a major epidemic non-communicable disease in the world. It has resulted in a socioeconomic loss to the country and the community at large. RTA poses a major problem in huge proportions in many places, mostly in industrialised populations. In the developing world, current rate of increased population growth, industrialisation and urbanisation are putting heavy pressure on the transport network in general and on road system in particular. Some of the unwanted side effects of this growth in traffic, such as congestion and noise are immediately obvious to the individual citizen. Others such as the growing number of deaths and injuries from road traffic accidents (RTAs) are apparent only through aggregated statistics. These reveal a serious and growing problem, with absolute fatality and casualty figures rising rapidly in the majority of developing countries and with death rates considerably higher than in the developed world.

The study aims to understand the pattern of extremity fractures amongst patients attending Orthopaedic OPD \& Emergency at Jawaharlal Nehru Institute of Medical Sciences, Imphal. Analysis of fracture epidemiology from the study will help clinicians to determine definable and preventable characteristics that predispose to skeletal fracture and planning of appropriate treatment strategies.

\section{MATERIALS AND METHODS}

The prospective study was conducted over a period of 3 years i.e. from 1st January 2013 to 31st December 2015 at Jawaharlal Nehru Institute of Medical Sciences, Imphal, Manipur. For the study, patients of all age groups attending Orthopaedics OPD and Casualty Department of the Institute with musculoskeletal injuries following trauma were included in the register. In case 
of minor patients and patient with altered sensorium, history was taken from guardian/relatives of the patient. History taken was to ascertain the mode of injury in each case. Detailed clinical examination followed by x-ray of the part (Anteroposterior, lateral and or oblique views) were taken for each patient to establish the diagnosis and to find out the particular bone being involved and to know the site of involvement. Any associated dislocation was also noted. Fractures of upper extremity and lower extremity were separately grouped. Particular bone involved and its site of involvement was also noted region wise as shown in the Tables no. $1 \& 2$.

All metatarsal, metacarpal, carpal, tarsal and phalangeal fractures are taken as one group each. Particular age groups affected were also noted and they are classified into 8 subgroups as 0-10 yrs., 11-20 yrs., 21-30 yrs., 31-40 yrs., 4150 yrs., 51-60 yrs., 61-70 yrs., 71 yrs. and above. Involvement of either right or left side of each individual fractures were also noted. A total of 1200 patients were recruited over a period of 3 years extending from $1^{\text {st }}$ January 2013 to $31^{\text {st }}$ December 2015. Cases of extremity fractures associated with injury to head, spine, chest, blunt abdominal trauma, pelvic fracture, etc. were also excluded from the study. Pure/isolated dislocations unassociated with fractures were excluded. All pathological fractures either due to infection or tumour were also excluded from the study. Fractures following gun shots and assault were also excluded from the study.

\section{RESULTS}

From Table no. 1, the most common fracture in upper extremity was found to be distal radius fracture $(n=240,20 \%)$ which is followed by fracture involving both bones of forearm $(\mathrm{n}=88,7.3 \%)$. Table no. 2 shows that the most common fracture involving lower extremities was fracture of both bones i.e. tibia and fibula together $(n=91,7.58 \%)$. The second common fracture was that of metatarsals $(n=70,5.8 \%)$. In the study, the most common age group was found to be between 31 to 40 years ( $n=296,24.5 \%)$ followed by 21 to 30 years age group ( $\mathrm{n}=286,23.8 \%$ ). The age group 41 to 50 years accounted for $180(15 \%)$ of the cases. There were 879 (73.5\%) male cases and $321(26.75 \%)$ female cases.

In the upper limb fractures, affection of left side was 354 $(50.72 \%)$ of the cases whereas in $344(49.28 \%)$ right side was affected. In the lower limb, right side was affected in 274 (54.58\%) cases \& left side was affected in 228 (45.42\%) of the cases.

The most common mechanism of injury was found to be 'fall' (68.75\%) followed by that of road traffic accident (18.92\%). Fall while working either on slippery or uneven surfaces due to bad road conditions was by far the most common cause followed by fall from height. In the upper limb fractures, common associated dislocation, e.g. shoulder dislocation, elbow dislocation, radio-ulnar dislocation, acromioclavicular dislocation, etc. were found in 25 cases. The commonest associated dislocation found in the series was that of shoulder dislocation.

In the lower limb, dislocation of hip and ankle were noted in 9 cases. Out of the 9 cases, hip dislocation was found in 3 cases and ankle dislocation in 6 cases.

\section{DISCUSSION}

The study was aimed to know the pattern of extremity fractures in patients suffering from traumatic injuries. It has been found that upper extremity injuries (58.16\%) are more common than that of lower extremity (48.83\%). Similar findings were observed in many other studies conducted in different parts of the country. ${ }^{3,4}$ This is explained from the fact that most of the trauma occurred in this region due to low velocity RTA, thus enabling the victims to use defence mechanism, hence causing more upper limb fractures than lower limb fractures. Fractures involving distal end of radius $(20.0 \%)$ has been found to be the most common fracture in the study. Shahen M.A. et $\mathrm{al}^{5}$ reported fractures of radius and ulna together in $25.57 \%$ of the total cases being studied by them.

The commonest mode of injury was found to be fall-related injuries $(68.75 \%)$ followed by that of road traffic accident $(18.92 \%)$. The reason could be slippery road, uneven road conditions, etc. It is usual human tendency to use upper limbs for defence mechanism to prevent fall. In case of road traffic accidents, fractures involving both bones of lower limbs are more common as the bones of legs are superficial with very little soft tissue to absorb the forces of impact. Some studies conducted in North East Karnataka have reported lower limb involvement (59.91) is much higher compared to involvement of upper limb bones (30.66\%). ${ }^{6}$ Comparable results have also been reported by other authors like Archibong A.E. et $\mathrm{al}^{7}$, Akiode 0. et al ${ }^{8}$, Okaro I.O., Ohadugha C.0. ${ }^{9}$ A study from Vietnam points to fall in elderly individuals as a major cause of extremity fractures while road traffic accidents are responsible for most fractures in children.

Age groups from 21-30 years (23.8\%) and 31-40 years (24.5\%) were the two most commonly affected age groups. The two groups accounted for $48.3 \%$ of the total fracture cases. Higher incidence of fractures in this age groups could be related to the fact that there has been tremendous increase in the number of vehicles plying on the roads which are not only congested but also poorly maintained.

Similar studies conducted by Meena R.K., Singh A.M., Singh C.A. et $\mathrm{al}^{4}$ found that most patients were in the age group of 3140 years $(24 \%)$ followed by $21-30$ years $(20 \%)$. The two age groups accounted for $44 \%$ of all trauma victims. In our study, slightly higher percentage is found in the age group of 21-30 years, the figures are comparable in the age group of 31-40 years. These age groups were the most productive, highly stressful and mobile group. Jha N, Srinivasa DK et al ${ }^{10}$ in their study of injury pattern among road traffic accident cases in a tertiary hospital in South India found that more than 53\% of the victims were in the age group between 20-40 years. Akinpelu $0 \mathrm{~V}$, Oladele et al ${ }^{11}$ in their study of road traffic accidents in a Nigerian tertiary hospital observed that total of $47.3 \%$ trauma admissions were in the third and fourth decade of life, with mean age as 32 years.

The male to female ratio in the study is 2.7:1. Meena R.K., Singh A.M. et $\mathrm{al}^{4}$ in their study found that male to female ratio was $2.5: 1$.

Swarnkar M, Singh P et al ${ }^{12}$ in their study of trauma in Central India observed that the male to female ratio was 3.9:1. Okaro I.O. et $\mathrm{al}^{9}$ in their study of anatomic pattern of fractures and dislocations among accident victims observed that the male to female ratio to be $1.8: 1$.

In the present study in the upper limb fractures, left side $(n=354,50.72 \%)$ was slightly more commonly affected than right side $(n=344,49.28 \%)$. In case of lower limb fractures, right side $(\mathrm{n}=274,54.58 \%)$ found to be more commonly affected than the left side $(n=228,45.42 \%)$. M. A. E. Shaheen et 
al in their study of limb fractures, 52.6 percent occurred on the left side and 47.4 percent on the right side.

From this study, it has been found that mode of injury may play an important role in determining pattern of fractures involving bones of both upper and lower extremities. Therefore, understanding the pattern of fractures may be helpful in making future plans for prevention and in working out of management strategies of extremity fractures.

\section{CONCLUSION}

The present study shows that most of the causes of trauma are preventable. As fall related injuries and road traffic accidents are responsible for maximum number of cases, proper maintenance of the roads and strict traffic regulation will help in reducing the number of fractures. Upper limb fractures are more common than lower limb fractures. Among the upper extremity fractures, distal end of radius is most commonly affected whereas fracture involving both bones of legs is the most common lower extremity fracture. Awareness campaign regarding strict traffic regulation and safe driving practices may be targeted at the high risk groups (Adult males and students). Knowledge gained from the study will be helpful for hospital authorities for better planning of trauma centres thereby improving the overall patient care services and its ultimate outcome.

\begin{tabular}{|l|c|c|c|}
\hline \multirow{2}{*}{$\begin{array}{c}\text { Bone and Site } \\
\text { Involved }\end{array}$} & \multicolumn{2}{|c|}{ Side } & \multirow{2}{*}{ Total } \\
\cline { 2 - 3 } & $29(2.42)$ & $31(2.58)$ & $60(5)$ \\
\hline $\begin{array}{l}\text { Clavicle } \\
\text { humerimal end of }\end{array}$ & $14(1.17)$ & $19(1.58)$ & $33(2.75)$ \\
\hline Shaft of humerus & $13(1.08)$ & $11(0.92)$ & $24(2)$ \\
\hline $\begin{array}{l}\text { Supracondylar } \\
\text { humerus }\end{array}$ & $36(3.00)$ & $33(2.75)$ & $69(5.75)$ \\
\hline $\begin{array}{l}\text { Distal end of } \\
\text { humerus }\end{array}$ & $13(1.08)$ & $9(0.75)$ & $22(1.83)$ \\
\hline $\begin{array}{l}\text { Olecranon } \\
\text { process of ulna }\end{array}$ & $4(0.33)$ & $6(0.50)$ & $10(0.83)$ \\
\hline $\begin{array}{l}\text { Head or neck of } \\
\text { radius }\end{array}$ & $11(0.92)$ & $9(0.75)$ & $20(1.67)$ \\
\hline $\begin{array}{l}\text { Both bones of } \\
\text { forearm }\end{array}$ & $45(3.75)$ & $43(3.58)$ & $88(7.33)$ \\
\hline Radius & $11(0.92)$ & $20(1.67)$ & $31(2.58)$ \\
\hline Ulna & $12(1.00)$ & $13(1.08)$ & $25(2.08)$ \\
\hline $\begin{array}{l}\text { Distal end of } \\
\text { radius }\end{array}$ & $\begin{array}{c}109 \\
(9.08)\end{array}$ & $131(10.92)$ & $240(20)$ \\
\hline Carpal bones & $5(0.42)$ & $4(0.33)$ & $9(0.75)$ \\
\hline Metacarpal bones & $25(2.08)$ & $12(1.00)$ & $37(3.08)$ \\
\hline Phalanges & $13(1.08)$ & $8(0.67)$ & $21(1.75)$ \\
\hline $\begin{array}{l}\text { Multiple bone } \\
\text { fractures }\end{array}$ & $4(0.33)$ & $5(0.42)$ & $9(0.75)$ \\
\hline $\begin{array}{l}\text { Tatal } \\
(28.67)\end{array}$ & $354(29.50)$ & $\begin{array}{c}6988 \\
(58.16)\end{array}$ \\
\hline
\end{tabular}

Figures in parenthesis indicate percentages.

\begin{tabular}{|c|c|c|c|}
\hline \multirow{2}{*}{$\begin{array}{l}\text { Bone and Site } \\
\text { Involved }\end{array}$} & \multicolumn{2}{|c|}{ Side } & \multirow{2}{*}{ Total } \\
\hline & Right & Left & \\
\hline $\begin{array}{l}\text { Intracapsular } \\
\text { fracture femur }\end{array}$ & $17(1.42)$ & $8(0.67)$ & 25 (2.09) \\
\hline $\begin{array}{l}\text { Intertrochanteric } \\
\text { fracture femur }\end{array}$ & $27(2.25)$ & $25(2.08)$ & $52(4.33)$ \\
\hline Shaft of femur & $29(2.42)$ & $18(1.50)$ & $47(3.92)$ \\
\hline $\begin{array}{l}\text { Supracondylar and } \\
\text { Intercondylar femur }\end{array}$ & $6(0.50)$ & $4(0.33)$ & $10(0.83)$ \\
\hline Patella & $16(1.33)$ & $20(1.67)$ & $36(3.00)$ \\
\hline Proximal end of tibia & $17(1.42)$ & $12(1.00)$ & $29(2.42)$ \\
\hline Tibia & $13(1.08)$ & $17(1.42)$ & $30(2.50)$ \\
\hline Fibula & $5(0.42)$ & $3(0.25)$ & $8(0.67)$ \\
\hline Both-bone leg & $49(4.08)$ & $42(3.50)$ & $91(7.58)$ \\
\hline Bimalleolar & $12(1.00)$ & $9(0.75)$ & $21(1.75)$ \\
\hline Medial malleolus & $8(0.67)$ & $6(0.50)$ & $14(1.17)$ \\
\hline Lateral malleolus & $10(0.83)$ & $12(1.00)$ & $22(1.83)$ \\
\hline Calcaneum & $9(0.75)$ & $8(0.67)$ & $17(1.42)$ \\
\hline Other tarsal bones & $2(0.17)$ & $2(0.17)$ & $4(0.33)$ \\
\hline Metatarsals & $41(3.42)$ & $29(2.42)$ & $70(5.83)$ \\
\hline Phalanges & $8(0.67)$ & $9(0.75)$ & $17(1.42)$ \\
\hline Multiple fracture & $5(0.42)$ & $4(0.33)$ & $9(0.75)$ \\
\hline Total & $\begin{array}{c}274 \\
(22.83)\end{array}$ & $\begin{array}{c}228 \\
(19.00)\end{array}$ & $\begin{array}{c}502 \\
(41.83)\end{array}$ \\
\hline Tab & xtremity & acture Pc & \\
\hline
\end{tabular}

Figures in parenthesis indicate percentages.

\begin{tabular}{|c|c|c|}
\hline Types of Injury & Number & Percentage \\
\hline Fall & 825 & 68.75 \\
\hline RTA & 227 & 18.92 \\
\hline Others & 148 & 12.33 \\
\hline \multicolumn{2}{|c|}{ Table 3: Showing Mechanism of Injury } \\
\hline
\end{tabular}

\begin{tabular}{|c|c|c|}
\hline Types of Fall & Number & Percentage \\
\hline Fall while walking & 510 & 42.50 \\
\hline Fall from height & 196 & 16.33 \\
\hline Fall from stair case & 163 & 13.58 \\
\hline Unexplained falls & 331 & 27.58 \\
\hline \multicolumn{3}{|c|}{ Table 4: Showing Different types of Fall } \\
\hline
\end{tabular}

\section{REFERENCES}

1. Maciaux M, Romer CJ. Accidents in children and young adults. Major public health problem. Wld hlth stat Quart 1986;39:227-31.

2. Onotade FJ, Fatusi OA, Ojo MA. Call hour maxillofacial emergencies presenting to a Nigeria teaching hospital. African Journal of oral health 2004;1(1):17-24.

3. Verma PK, Tewari KN. Injury prevention and control: an epidemiological study of injuries in the area of municipal corporation of Delhi. World Health Organisation 2003. Available from:

http://www.searo.who.int/LinkFiles/whd04_Documents _Accidents-7.pdf.

4. Meena RK, Singh AM, Singh CA, et al. Pattern of fractures and dislocations in a tertiary hospital in North East India. Int Jr Epidemiol 2013;11(1):13-5.

5. Shaheen MA, Badr AA, Khan FA, et al. Patterns of accidental fractures and dislocations in Saudi Arabia. Injury 1990;21(6):347-50.

6. Bhaskara K, Padmanabha TS, Nandini T, et al. Pattern of fractures and dislocations in a tertiary care hospital, North East Karnataka. Int Jr Med Res Health Science 2014;3(4):847-50. 
7. Archibong AE, Onuba O. Fractures in children in South Eastern Nigeria. Central African Jr Med 1996;42(12): 340-3.

8. Akiode O, Shonubi AM, Musa A, et al. Major limb amputations: an audit of indications in a suburban surgical practice. J Natl Med Assoc 2005;97(1):74-8.

9. Okaro IO, Ohadugha CO. The anatomic pattern of fractures and dislocations among accident victims in Owerri, Nigeria. Niger Jr Surg Res 2006;8:54-6.
10. Jha N, Srinivasa DK, Roy G, et al. Injury pattern among Road traffic accident cases: a study from South India. Indian Journ of Comm Med 2003;28(2):85-90.

11. Akinpelu OV, Oladele AO, Amusa YB, et al. Review of road traffic accident admissions in a Nigerian tertiary hospital. East and Central Afr journ of surg 2007;12(1):63-7.

12. Swarnkar M, Singh P, Dwivedi S. Pattern of trauma in central India-an epidemiological study with special reference to mode of injury. The Int Journ Of Ep 2010;9:1. 